\title{
PERCEPTION OF MARGINALITY AND PERIPHERALITY IN AN IRISH RURAL CONTEXT
}

\author{
Lucia Málikován ${ }^{1}$, Maura Farrell² ${ }^{2}$ John McDonagh ${ }^{2}$ \\ ${ }^{1}$ Department of Human Geography and Demography, Faculty of Natural Sciences, \\ Comenius University in Bratislava, Slovakia \\ ${ }^{2}$ Rural Studies Research Cluster, National University of Ireland, Galway, Ireland \\ Manuscript received: October 9, 2014 \\ Revised version: October 4, 2016
}

\begin{abstract}
Máliková L., Farrell M., McDonagh J., 2016. Perception of marginality and peripherality in an Irish rural context. Quaestiones Geographicae 35(4), Bogucki Wydawnictwo Naukowe, Poznań, pp. 93-105, 1 table, 3 figs.

ABSTRACT: The existence of marginal regions is closely linked to the socio-spatial polarisation of our society. Although marginality and peripherality can be considered a multidimensional phenomenon, the literature as well as social discourses often address only some of its dimensions, in particular on the basis of objective approaches. Such a research is usually based on the quantification of a wide range of statistical indicators, whether of a social, environmental or economic nature. This study aims to capture another equally important dimension of this phenomenon, namely the perception of marginality and peripherality. Drawing on a series of interviews carried out with experts in the field of Irish rurality, this research points to the various perceptions of this phenomenon in rural Ireland. The results once again confirm the complexity of marginality and peripherality, and highlight many differences but also similarities that exist with regard to this phenomenon in the Irish rural context.
\end{abstract}

KEY WORDS: perceptual marginality, peripherality, rural areas, interview, Ireland

Corresponding author: Lucia Máliková, Department of Human Geography and Demography, Faculty of Natural Sciences, Comenius University in Bratislava, Slovakia, Ilkovičova 6, Mlynská dolina, 842 15, Bratislava, Slovakia; e-mail: malikova@fns. uniba.sk

\section{Introduction}

Under the influence of the global transformation of society, rural areas have begun to change significantly, either in terms of the basic structure of their population, diversification of economic activities, or the nature of the countryside (Woods 2007). These changes are reflected not only in the increasing heterogeneity of rural areas, but also in their different socio-economic status. Rural-urban divisions have deepened, creating the image of the rural as an 'outsider' in society and of rurality as synonymous with 'backwardness'. Rural restructuring has created further internal divisions, with some segments of the countryside stagnating and gradually declining, and others remaining buoyant (Buchta 2003). In describing these regions of stagnation as peripheral or marginal, Máliková and Spišiak (2013) suggest their negative status. Using preselected indicators - economic, social, demographic or environmental - they apply a multidimensional concept. Despite their similarity, there is quite a considerable dichotomy in the perception of both terms and therefore the interpretation of this phenomenon is different. This could be attributed to their general, ethical and political background and different meanings at different 
scales (Leimgruber 1994), or its changing importance over time (Andersson 2007) depending on the prevailing paradigms and philosophies of the time (Hurbánek 2004a). The ambiguity of this phenomenon as well as various aspects through which peripheral/marginal rural areas can be studied provide a wide scope for academic research.

A considerable part of research in this area is based on conventional approaches using a quantitative analysis of selected statistical indicators which reflect the regions' marginal or peripheral status. Generally, the most common indicators are the population density, unemployment rate, educational level, economic activity, or distance from an urban (regional) centre (Maliková 2013). This methodology, however, raises questions as to the extent to which a certain area may be called marginal or peripheral only on the basis of statistical data. Although statistical data are a relevant source of information, they fail to provide a holistic representation of marginal and peripheral regions. This ambiguity is partly reflected by Andreoli (1994), who differeniates between the two terms, peripheral and marginal. In doing so, she suggests that border regions can be peripheral in terms of the geographical location, but their socio-economic situation can be more advanced than of a central region. On the other hand, not every marginal region is necessarily peripheral; for instance, regions with underdeveloped socio-spatial relationships can have a more favourable position with respect to the urban or regional centre.

This article seeks to examine marginality and peripherality in an Irish rural context through the lens of a qualitative approach focusing on the perception of this phenomenon from the perspective of different attitudes of selected rural actors. It draws on the work by Schmidt (1998), whose perceptual marginality represents a specific approach to the research on marginal and peripheral regions.

\section{Theoretical background: conceptualisation of marginality and peripherality}

Socio-spatial polarisation is currently a widely discussed topic not only in geography, but also in other academic fields, such as sociology, economics, political science, etc. With a growing number of studies, a variety of approaches to the identification of marginal areas have been developed across the scientific disciplines. Many studies are based on the core-periphery polarisation model as presented by Schmidt (1998), where periphery is seen as part of the territory insufficiently integrated into structures dominant in a given place and time, or in a modified continuum core, resulting in peripherality and marginality being identified as marginal areas where inclusion structures have failed (Andreoli 1994). On the other hand, Leimgruber (2004) defines marginal regions as those situated outside the main spatial system and ongoing social processes. The difference between peripheral and marginal regions then lies in their uneven levels of integration into this system. While periphery can be seen as an area linked to socio-cultural and socio-economic networks, a marginal area cannot be seen as an integral component of this system (Seidl, Chromý 2010). Chromý (2003) and Havlíček (2003) define periphery as an area that has not reached a certain degree of functional-spatial and socio-spatial relations, although according to other authors (Marada 2001; Jeřábek et al. 2004; Havlíček et al. 2005; Chromý, Janů 2008) this definition is relative and depends on the selected criteria of peripherality. Thus, the core-periphery concept represents one of the key models of geographical enquiry, and from the perspective of a significant number of authors it is also of vital importance especially in the context of peripheral and marginal regions (Leimgruber 2004). Besides the already mentioned authors, the core-periphery model is also discussed in Crewe's (1991) study of the changing perception of marginality, or in Cullen and Pretes (2000), who analyse the meaning and perception of marginality in social sciences.

Quite a different approach to defining and understanding the concept of marginality can be found in Falt'an et al. (1995), who emphasise the importance of acknowledging marginality not only as a state, but mainly as a process (the process of marginalisation) influenced by socio-economic changes that can affect a particular region either in a positive (mitigation of marginality) or a negative way (deepening of marginality). Similarly, an original perspective on marginality 
was indroduced by Mehretu et al. (2000). Those authors focus on marginality through processes that cause it, and distinguish its two basic forms: contingent (as a result of competitive inequality) and systemic (e.g. the influence of a totalitarian regime), as well as two secondary forms: collateral (as a result of regional negative contagion effects) and leveraged marginality (as a result of an economic pressure leading to marginalisation).

McDonagh (2002a) points out that in most studies conventional approaches and definitions are used to define peripherality, underlying its particular spatial aspect (periphery in terms of geographical isolation, rurality, and poor accessibility of an area). However, changes in communication and information technology nowadays significantly reduce the importance of the geographical location, and the spatial aspect seems to be less important. It is therefore essential to take into account also non-spatial aspects, which play an important role here. In this respect, McDonagh (2002a: 100) suggests that "It is becoming increasingly apparent that it is no longer possible to deal with merely physical space; but a more appropriate model is to deal with a multiplicity of social spaces which overlap the same geographical area. Essentially becoming aware of a different type of peripherality, becoming aware of 'aspatial' peripherality". Nonetheless, it would be inappropriate to ignore the fact that a gradual transition from spatial to non-spatial or aspatial aspects relates not only to the understanding and interpretation of marginality and peripherality, but can also be widely applied to rural areas (Hurbánek 2004b). This is a consequence of the main theoretical-methodological trends in $20^{\text {th }}$ century geography represented by a shift from a positivist interpretation of rural, as a part of 'spatial science', to a post-structural and post-modern interpretation of rural as more social, moral and cultural space (Johnston et al. 2000; Woods 2011).

A partial shift from a purely spatial approach to peripherality can also be seen in Czech studies where authors focus on so-called internal periphery'. Thus, internal periphery, unlike its external form (traditionally perceived in terms of geographical location, e.g. along a state border), can be found in a country, on the outskirts of impact of regional centers (Jakešová, Vaishar 2012), or in economically weak areas along regional borders (Perlín et al. 2010). Similarly, Musil and
Müller (2008) identified an internal periphery using only selected sociological indicators in the first stage of their research, followed by indicators reflecting spatial attributes. Even this methodology confirmed that attributes of peripherality could be identified along a border as well as in a country. However, the above definitions and methodologies represent only a general perception of peripherality and marginality. Andersson (2007) states that the view of marginality and the very meaning of this term has been changing and evolving significantly over time. Moreover, he suggests that even the scientific community uses this term more implicitly than explicitly, as shown by the fact that the term itself is not included in the Dictionary of Human Geography (Gregory et al. 2009). In this regard, McDonagh (2002a) adds an interesting remark that in fact we all know what peripherality is, unless we are asked to define it by ourselves. The diversity of research on the issue of marginality and peripherality arises not only from the ambiguous understanding of both terms, but also from different research bases. Taking into consideration the multidimensional nature of this phenomenon as well as drawing on the concepts developed by Leimgruber (1994, 2004), Sommers and Mehretu (1998) as well as Schmidt (1998), six elementary approaches can be recognised (see Table 1).

This study aims to highlight one of the neglected approaches: a subjective one, and discusses the perception of marginality and peripherality in the context of rural areas in Ireland. On the one hand, according to Leimgruber (2004), the perception of marginality can be considered an integral part of a social approach to it. He claims that the research on marginality should be based on the values of society that form the basis of human behaviour and decision-making. Thus he shifts attention even closer to the origin of human action, values and view of the world. On the other hand, Schmidt (1998) considers perceptual marginality as an individual subjective approach, as a subjective reality. She distinguishes a so-called internal and external perception of marginality. An internal perception of marginality is formed by individuals living in the area in question, while external perception can be understood as a view from the external environment, e.g. by groups directly unrelated to this area (the scientific community, experts, etc). 
Table 1. Partial approaches to marginality.

\begin{tabular}{|c|c|c|}
\hline \multicolumn{2}{|c|}{ Approach } & Description \\
\hline & Geometric & $\begin{array}{l}\text { Marginality in terms of spatial remoteness, peripheral location. Thus, a marginal region is one } \\
\text { situated on the geometric periphery of a larger area e.g. a state. }\end{array}$ \\
\hline & Ecological & $\begin{array}{l}\text { In this case, there are two approaches: ecological marginality in terms of environmental condi- } \\
\text { tions, or economic marginality in terms of limited natural potential for economic activity. }\end{array}$ \\
\hline$\stackrel{\substack{y \\
\frac{U}{0}}}{0}$ & Economic & $\begin{array}{l}\text { Identification of marginal regions in terms of economic factors and processes. Currently, } \\
\text { there is a shift from a strictly economic to a socio-economic approach and research based on a } \\
\text { quantitative evaluation of economic, demographic and social indicators with an emphasis on } \\
\text { economic development. }\end{array}$ \\
\hline & Social & $\begin{array}{l}\text { This approach emphasises factors causing marginalisation. Here marginal are certain pop- } \\
\text { ulation groups where the process of their socialisation has been interrupted. It is based on a } \\
\text { thorought analysis of demographic and social indicators. }\end{array}$ \\
\hline & Political & $\begin{array}{l}\text { Here marginalisation is a condition of an area that is under a negative influence of a political } \\
\text { border, historically significant events, or the distribution of supported and neglected regions. }\end{array}$ \\
\hline 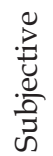 & Perceptual & $\begin{array}{l}\text { In this context, marginality is a matter of subjectivity reflecting individual attitudes and per- } \\
\text { ceptions. Thus, a marginal region is one perceived to be marginal by its inhabitants or from the } \\
\text { perspective of different actors. }\end{array}$ \\
\hline
\end{tabular}

Source: based on Leimgruber (1994, 2004), Sommers and Mehretu (1998), and Schmidt (1998).

\section{Methodology}

This paper focuses on the perception of marginality and peripherality from different perspectives of rural actors, in terms of external actors and experts as understood by Schmidt (1998). Unlike in the traditional research in this field, qualitative methods are used here. Qualitative methods have become increasingly important in the practice of human geography (Limb, Dwyer 2001), which is proved by the fact that this approach constitutes an important part of many studies, mainly because data of a subjective nature often reveal information which remains unknown when only quantitative statistical methods are used (Falt'an et al. 1995; Havlíček, et al. 2005; Vaishar, Zapletalová 2005; Džupinová et al. 2008). Limb and Dwyer (2001) also point out that qualitative methods are characterised by an in-depth approach, seeking a subjective understanding of reality rather than a statistical description and generalised predictions. Moreoever, combining both qualitative and quantitative approaches (also known as triangulation) represents an interesting direction in research, as pointed out by Šebová (2013), who emphasises possible correlations between the two methodologies. To represent the reality of the phenomenon discussed in this paper, a combination of quantitative and qualitative methods was deemed to be most appropriate.
In the context of this research, mainly qualitative methods including expert interviews and mental mapping were employed. Altogether seven individual rural experts ${ }^{1}$ were chosen for interviews, each with a different background (e.g. in sociology, economy, agricuture, or geography) and representing various institutions relevant in the Irish rural context (Teagasc, Irish Rural Link, Clare Local Development Company, Galway Rural Development Company), as well as one university academic whose research focuses on rural issues. The views of individual experts represent an interesting variety of angles from which marginality and peripherality can be approached, and thus offer a wide scope for further discussion and research. Although the number of interviews might be insufficient, it is appropriate to clarify that this research did not focus on the sample as a universal representation of Irish perceptions of the phenomenon of marginality and peripherality, but rather as a representation of significant rural experts' views and their positioning in this context.

The analysis of the interviews was preceded by several steps (Fig. 1). The interviews were transcribed in full, coded with both in-vivo codes

1 Every interviewee received a specific code (I-1, I-3, ...,I-7) and thus anonymity was ensured and his/her opinions and interpretations could be further incorporated into our analysis. 


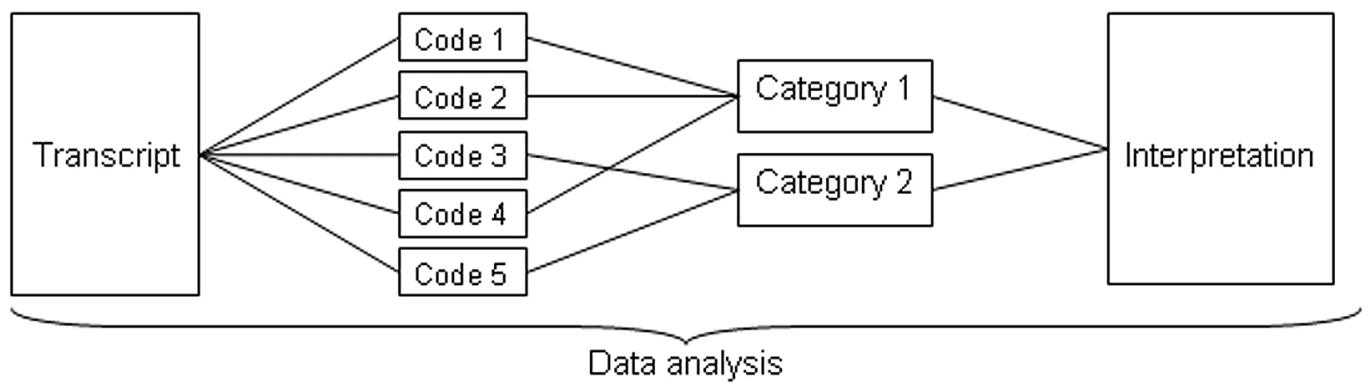

Fig. 1. Scheme of the interview analysis. Source: the authors.

and constructed codes, or meta-codes ${ }^{2}$, at a later stage, which enabled an examination of similarities, differences, connections and contradictions existing amongst the various participants, and a final interpretation of the results. The interview questions tackled various aspects, such as the perception and understanding of this phenomenon by individual participants; different types of marginality and peripherality; delimitation of these areas in the Irish rural context; key factors and processes influencing marginality and peripherality in Ireland, the position of those areas in the rural government and policy, and perspectives and proposals for marginal and peripheral rural areas.

As part of the interviewing process, the respondents were also asked to locate marginal and peripheral rural areas on the map of Ireland. In this case, a direct map creation was used for the interviewees to indicate which Irish locations they preceived to be marginal and peripheral. Mental mapping was applied as a suitable research technique, widely used by many researchers in geography and other disciplines, and allowed us to find out the spatial knowledge of the individuals and the structure and arrangement of such information (Bell 2009). Moreover, it enhanced our understanding of the phenomenon of marginality and peripherality as known by individual experts in the Irish rural context.

In our analysis, we were inspired by the methodology used by Shobe and Banis (2010), who presented a mental map of music regions in the USA based on students' perception. Thus, two differents outputs were created: a choropleth map

\footnotetext{
In-vivo codes are codes used by interviewees that the researcher regards as significant. Constructed codes are more analytical codes created by the researcher (Jackson in Limb and Dwyer 2001).
}

and an isoline map, both showing the composite response of all interviewees. The choropleth map was created by assigning a count to each county included in an interviewee's individual perception of marginal and peripheral areas, while the latter resulted from exact data digitisation into a GIS database. Where the perceptions of individual respondents overlaped, a final image or a mental map of marginal and peripheral rural areas was constructed.

\section{Perception of marginality and peripherality in the Irish context}

In this case study we chose to use qualitative methodology, which provided a great opportunity to answer a broad scope of research questions in terms of identification and perception, in addition to visually capturing the interviewees' perception of marginality and peripherality. The data gathered via seven individual expert interviews were analysed through a process of coding, and its interpretation was summarised in four tematic categories, all reflecting the main aspects that materialised.

Category 1: Understanding the phenomenon of marginality and peripherality

As previously declared, the concepts of marginality and peripherality are multidimensional (Labrianidis 2004), and this complexity was fully recognised by all interviewees irrespective of their academic background, profession or research interests. In this context, several related concepts were alluded to, such as the concept of rurality, periphery as a knowledge concept and conceptualisation in terms of social capital, which in turn further emphasises the complexity of the phenomenon and its broader impact. Irrespective 
of this diversity, a clear point was made in terms of the traditional understanding of this phenomenon through the lens of a geographical, spatial aspect. The connection between the geographical position of an area and its status of marginality or peripherality was acknowledged, but emphasis was placed on accessibility, mobility and connectivity as key determinants, which moved the relevance of distance to the background. As a result, the perception of geometric aspects shifts from looking through the distance of an area to its accessibility (Jeřábek et al. 2004). As declared by one our interviewees, "marginality and feeling on the edge or periphery is very different (...), you can also be very much not geographically isolated but have a feeling or sense of isolation or marginalisation. So it is not always about spacial location" (I-6).

At the same time, the opinion that marginality or peripherality is a matter of a subjective experience, state of mind, or even personal feeling prevails. This is related to the perception of a place as described in earlier works by Tuan (1977) and Relph (1976). In this respect, a place is understood as one based on various experiences and preferences, with people relating to it and attached to it, therefore it creates a so-called 'sense of place'. This notion was alluded to by one interviewee, who suggested that "maybe peripherality and marginality are not just economic or geographical, but maybe they are actually personal experiences, well in their own way ... Because when I think about marginality and I think about the kind of personal experience, about what it means to be marginal, I think about an income, I think about time and I also think about people..." (I-1). In a similar manner, another interviewee stated that "being marginalised is a very specific and a very subjective thing, ... so I don't know if I would agree with a strict definition that certain people living in certain areas are marginalised because they suffer from econmomic disadvantages, they live a certain distance from particular urban centers, they don't have a high level of education, their own subjective experience might not necessarily be marginalised, they might have good social networks, they might have a very good family support, they might have a very strong sense of place, they might have their own kind of idiosyncratic ways of surviving economically, and they are culturally informed" (I-2). A final comment from an interviewee also alluded to periperality as a state of mind, suggesting that "peripherality sometimes can be a physical, geographical thing, but it can also be almost a state of mind as well. So that's something I would always consider when I think of those terms in the Irish contex" (I-7).

The above statements point out the complexity and ambiguity of this phenomenon once again while stressing the importance of diversified approaches of individuals as far as the issue of marginality and peripherality is concerned. Marginality as a subjective phenomenon was emphasised in the earlier works by Schmidt (1998), Tykkyläinen (1998) and Andreoli (1989), with the perception of individuals and perceptual marginality in the spotlight of their studies. Tykkyläinen (1998) sees a connection between marginality and the perception of the degree of marginality by individuals in different locations, while Schmidt (1988) goes further to distinguish internal and external perception (see Theoretical background). Taking all this into consideration, we can conclude that subjectivity (in this context) matters, an individual approach is more than just necessary, and it is not just black and white when attributing a certain area the label of 'marginal', 'peripheral'. As Andreoli (1989) points out, marginality is more an intuitive concept, so we may say that its understanding depends on the ability to see the interconnection between its objective and subjective dimensions.

Category 2: Paradoxes and differences associated with the perception of marginality and peripherality

With regard to the delimitation of marginal and peripheral regions, one participant stressed that "what might objectively be seen as being marginalised is not necessarily the case (...), the delimitation of marginal and peripheral areas is often short-sight$e d^{\prime \prime}$ (I-2). It appears that theoretical approaches often neglect real conditions in a certain area and hence the reality of a given place or situation is not accurately reflected. Moreover, conventional theories and concepts of marginality and peripherality look at this phenomenon rather negatively, as it is rooted in well-known definitions by Leimgruber (1994), Andreoli (1994) and Schmidt (1998). According to those authors, being marginal or peripheral is usually interpreted as a disadvantage regardless of whether this interpretation is figurative (as a place with insufficient functional and spatial relationships) or literal (as being physically situated on the edge or on the periphery of a certain area). Nonetheless, 
the key aspects of marginality and peripherality were presented by the interviewees in a positive manner that stressed opportunities associated with peripheral regions rather than negative connotations. One interviewee suggested that "it is actually good sometimes to be an outsider, sometimes it's good to be peripheral. ... And I think in a way, you know, sometimes people in the west probably capitalise that feeling of being peripheral, you know it's a tourism tool as well in itself" (I-1). Another explained that "what you find with people is that they are actually quite proud of their areas, the areas where they live, they actually don't see peripherality as a drawback or a disadvantage, ... and they are there by choice, so obviously they see something in being marginal or living in the marginal areas actually as an advantage" (I-3).

Influenced by their own research and knowledge, most interviewees gave Connemara in the west of Ireland as a prime example of a marginal and a peripheral region that has capitalised on its location. They thought that because of its rather peripheral and remote location, Connemara was an example of a marginal area. They also suggested that the unique and natural, but remote and peripheral environment of Connemara favoured the tourist industry, which has become a sustaining influence in the region. Similar studies by Che (2006) and Conway and Cawley (2012) suggest that peripheral regions of high ecotourist value are increasingly favoured by the industry. Similarly, McDonagh (2002a) suggests that peripheral places where authentic isolation and remoteness has been transformed into a tourist attraction strategy are increasingly favoured as tourist destinations. This trajectory was recently highlighted in a report by the Commission for Economic Development in Rural Areas (CEDRA), which states that tourism based on place-specific identities has the potential to generate economic value in relatively peripheral rural areas.

Another example often given in the context of peripherality is borderland and its physical location on the edge of a state, where remoteness and peripherality often emanates from inaccessibility and a legacy of a back-to-back policy (Creamer et al. 2009). Although the general perception of the border as a barrier still persists in academic discourse, its nature keeps changing over time (Máliková et al. 2015). Specifically under the influence of globalisation, the general significance of the border as a barrier decreases in favour of cross-border cooperation (Jeřábek et al. 2004) built on the opening of borders that used to divide us (Newman 2006). Dingsdale (1999) points out that those links over national borders have created socalled corridors of co-operation. As stated by one of the interviewees with research experience in border regions, this trend can also be recognised in the Cross-Border Territory between Ireland and Northern Ireland where, despite the former conflict and political instability, co-operation in many spheres takes place: "I would see that physical and political peripherality has actually, rather than further isolate people, has actually driven individuals and communities to ensure that they access opportunity ... In fact, say a border region [meaning a border region in Ireland] is actually seen as one of the most entrepreneurial regions in the country, because they kind of take advantage of that" (I-7).

Category 3: Suggestions about factors and processes influencing marginality and peripherality

As mentioned in the literature, marginality and peripherality can be understood as both, a state and a process. Nevertheless, this phenomenon is affected positively or negatively by different endogenous (e.g. locality, potential, resources) and exogenous factors (e.g. historical development, state intervention). Some of our interviewees pointed to this phenomenon in a historical context, suggesting that the British occupation, famine and the traditional agricultural orientation of rural Ireland could be preceived as a historical burden somehow rooted in rural Ireland. The majority of participants share the view that although considerable attempts have been made to develop rural regions on an even basis, such attempts are unsuccessful in the more peripheral and marginal areas. A clear lack of joined-up thinking, an evidence-based approach and local engagement were given as key reasons for uneven development in a rural context. In this regard, the issue of a rural policy and governance and how they influence marginal and peripheral areas was considered. Here again, a negative and somewhat unsatisfactory attitude prevailed among the participants, who pointed out, for instance, that "in terms of rural development, a policy has a major impact. But you can look at other factors, I mean the government policy. The government policy, unfortunately, has not been as favourable. You had the National Spatial Strategy which was, I think, more an 
ideal ... So it looks good as a report, but the reality was never followed, it was not implemented" (I-3), or "that they [marginal and peripheral areas] are not considered by policy makers because there is a kind of disconnectedness between policy makers and the people on the ground... Again I would go back to rural proofing that decisions are made at the national level and are not just considered at the local level" (I-4).

Nonethless, all respondents were consistent in their certainty of the importance of the rural population, the role of communities, and the social capital that exists in peripheral areas. While stressing the importance of these aspects of those regions, several examples were given to support the arguments. Local leaders and their ability to generate social capital in peripheral areas was stressed and many alluded to the concept of a local champion. The following commentary of one interviewee represents this attitude best: "I would say human capital is big and a major driver of marginalisation, because if you have a person in a community willing to take something on and see it through to the end, and keeps things alive, it makes a massive difference. ... I really think that people do matter, and leaders do matter, and having somebody in the community who is pro-active and getting people together and willing to give them their time..." (I-6).

Category 4: Proposals of activities and actions necessary to deal with marginality and peripherality

In the previous section, the importance of social capital was highlighted. What became obvious as a result of interviewee comments is the imperative nature of community involvement and participation to ensure development and sustainability. People are identified as of key significance in the implementation of change and development in rural areas lagging behind. With such statements as "people's perspectives need to be brought more into the fore" (I-1) or "there isn't enough avenues that would allow the voice of the community" (I-2), all respondents emphasise the need for the involvement of a local perspective, participation and cooperation in the decision-making process, which is imperative for future planning and development. The following comments stress these points.

Given the ambiguous interpretation of this phenomenon itself, it is also necessary to recognise the diversity of rural space, emanating not only from diversified geographical locations and characteristics, but also from rural people's perception of it (Woods 2005), and the appreciation of its unique features might be beneficial to use, as already mentioned in the example from Connemara. "There is no one-size fit. Communities are diverse, and that's why Ireland is a special country in that regard, it is very different from one edge of the country to another" (I-4). "It is about countryside capital, about what already exists and taking advantage of that and the communities that I see who are marginalised, who are geographically peripheral, communities and areas or regions that are becoming successful or are successful are the ones who said what we have here, what is good for you. ... I don't think it is about reinventing the wheel, I don't think it is about creating something new. It is about saying what we have, what exists, what works and what we are good $a t^{\prime \prime}(\mathrm{I}-7)$.

Last but not least, an inspiring concept was presented by one interviewee with regard to improving the status of marginality and peripherality in rural Ireland: "So is it possible to reverse it [marginality and peripherality]? I'm not sure it should be reversed. I think what actually needs to happen is some kind of a re-creation of something that is actually better" (I-1).

In addition to the oral questions, a map exercise was conducted, positively reflected upon by all participants. Two map interpretations provide a great example of a general spatial perception of marginality and peripherality. Although in this case we only capture the perspective of seven experts, our aim was not to provide a representative sample, but perceptions of different rural actors and similarities between their opinions. As a result, the first map (Fig. 2) shows distribution patterns in relation to marginality and peripherality, closely linked to geographical locations, namely, the western seabord. Moving towards the eastern counties, the perception of marginality and peripherality is expressed to a much lesser extent. It is also interesting that except for 5 counties all others (or their parts) were perceived to be marginal or peripheral at least once. Even some parts of Dublin, generally seen as a core and thriving region, were mentioned in the context of marginalisation, with one individual commenting that "...for instance there is an area here like in Dublin, this area that I did a lot of research in the past that I would see is very marginal. Marginal maybe in a different way to here [west] because in the west, for 


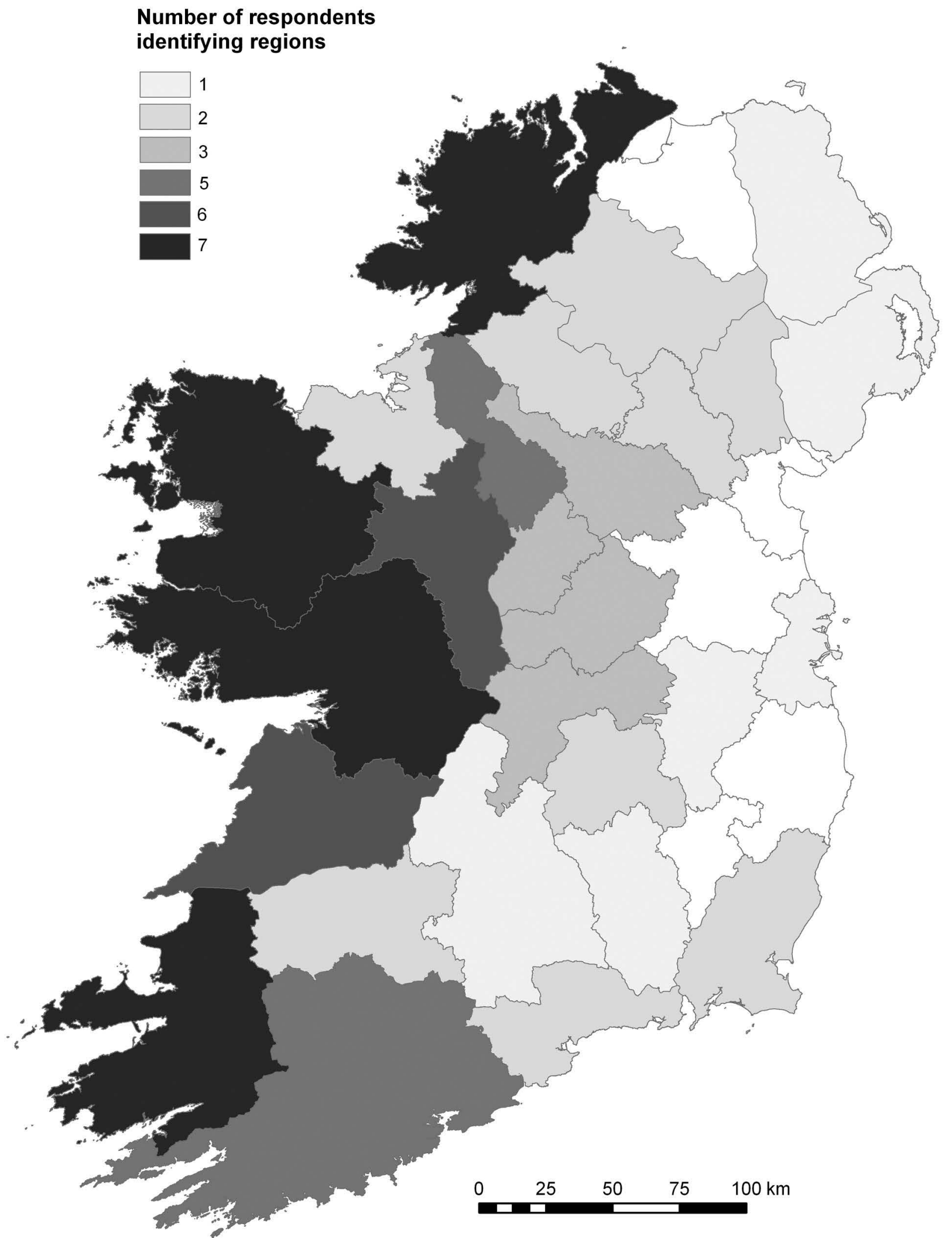

Fig. 2. Perception of marginality and peripherality in Ireland from the perspective of selected rural actors (a choropleth map).

Source: the authors 


\section{Number of respondents} identifying regions

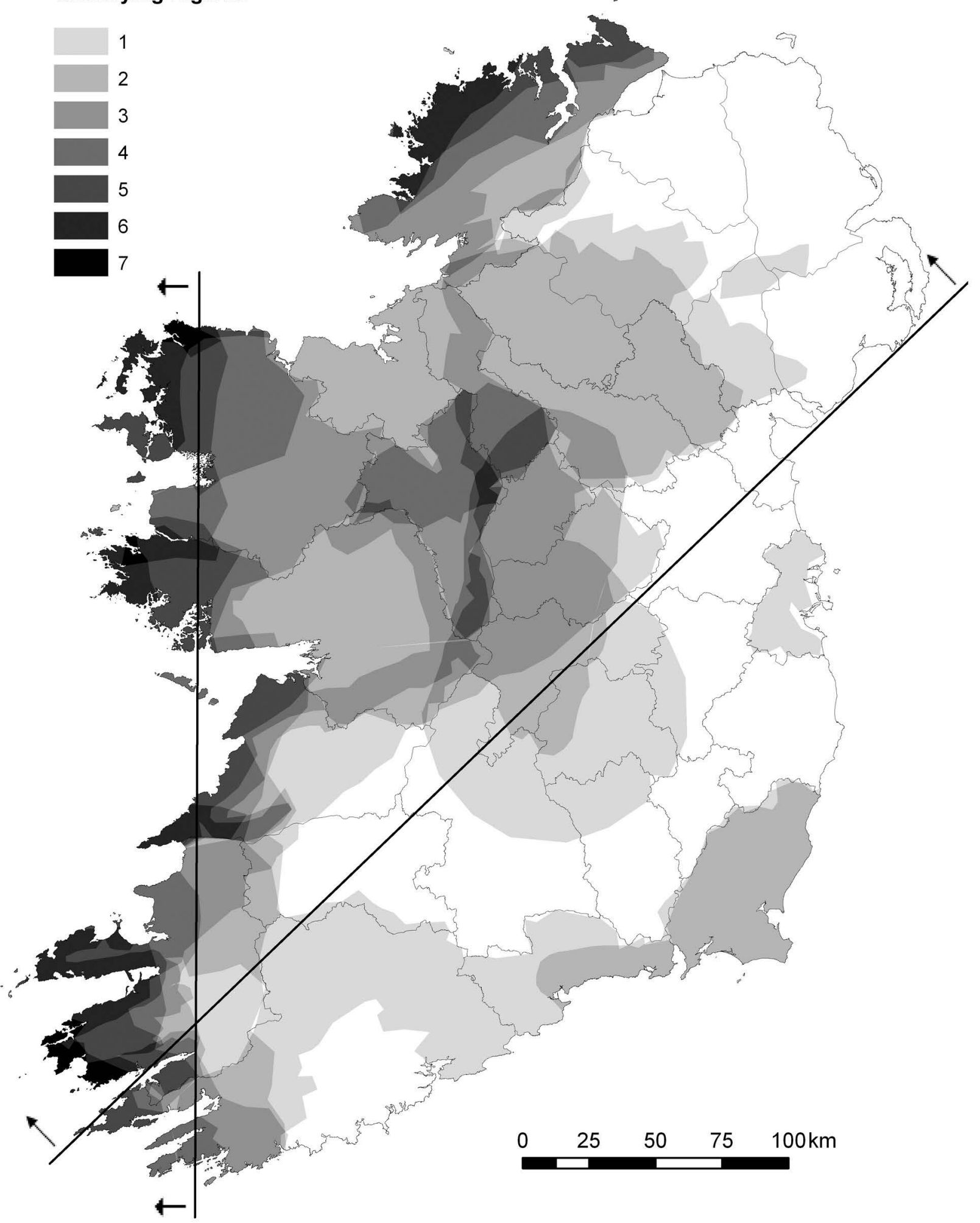

$\leftarrow$ Trend of spatial polarization and increase of the intensity of marginality

Fig. 3. Perception of marginality and peripherality in Ireland from the perspective of selected rural actors (an isoline map). Source: the authors. 
instance, there is a common perception that the west is underdeveloped ... but I mean there are some areas, for instance in Dublin, that are extremely marginal, and I mean marginal in terms of unemployment rates, socially very very disadvantaged, very few resources for young people and adults, etc." (I-1).

Since a choropleth map provides only a rough idea about counties included in the description of marginal and peripheral areas in a certain way, it is an isoline map that corresponds best with the delimitation of those areas from the perspective of all participants (Fig. 3). Thus, a mental map can reveal a lot about the spatial distribution of marginal and peripheral areas in Ireland as perceived by different actors, while enabling us to explore differences and similarities using theoretical concepts and a general understanting of this phenomenon. In our case, the second map seems to be more optimistic than the first, since areas identified as the most marginal and peripheral are those located on the edge of peninsulas along the western seabord. In general, two divisions can be seen in this spatial distribution. On the one hand, this phenomenon occurs quite commonly in north-western Ireland, and on the other, its extreme concentration is the most pronounced on the west coast. This pattern corresponds to the general association of marginality and peripherality with western and north-western Ireland (Creamer et al. 2009; McDonagh 2002; CEDRA report).

\section{Discussion and conclusions}

The rural environment as we know it has begun to change significantly under the influence of the global economy. Thus, rural areas can be seen as a continuous space of change (Woods 2005), the changes being both qualitative and quantitative, and taking place in social structures and practices, generally described as 'restructuring' (Hoggart, Paniagua 2001).

Many authors have done an intensive research on marginality and peripherality, which are very often associated with rural areas. With the growing number of these studies, different approaches to the identification of marginal areas have been developed, with a quantitative approach being favoured. In this study we adopted another approach, based on qualitative methods: perceptual marginality. A mental map reveals an interesting pattern of perceptual marginality from the perspective of different rural actors. This image of marginal and peripheral areas corresponds more or less to the general view of the distribution of this phenomenon across Ireland in the literature, with mainly the western part of Ireland, in particular Connaught province, presented as the most pronounced in this respect. Despite a gradual change in the understanding of the phenomenon of marginality and peripherality and a shift of emphasis from spatial to non-spatial aspects (McDonagh 2002a), also presented by our interviewees, the geographical location and distance are still relevant factors to a certain extent (McDonagh 2002b). On the other hand, the multidimensional nature and complexity of this phenomenon was corroborated as well. In this respect, several authors emphasise a comprehensive approach (Ferrão, Lopes 2004) or in other words a holistic approach (Labrianidis 2004) to the understanding of peripherality, especially in the context of the rural environment.

Another significant outcome is the way this phenomenon is presented in the views of different persons. Although their academic and professional background varies from one person to another, they shared rather similar opinions, highlighting various aspects and supporting them by their own research experiences. A very strong connection between marginality and a community can be recognised, building upon the role of the community and especially local leaders, local champions, in the development of certain marginal or peripheral rural areas. Local awareness, the appreciation of local assets and potential and participation were considered to be among the key factors necessary to face marginalisation. Last but not least, a double effect of marginality and peripherality was emphasised, understanding it in a traditionally negative sense on the one hand, while taking advantage of it, e.g. through tourism, on the other, as demonstrated by McDonagh (2002a).

By stressing the complexity of the phenomenon of marginality and peripherality, we tried to enrich and contribute to the existing literature by applying mental mapping procedures and revealing patterns of its perception in the Irish rural context. Some well-known information was confirmed again, some new interesting ideas came 
along, providing new possible directions for the research of marginality and peripherality, thus unfolding another layer in its complex nature.

\section{Acknowledgements}

This study was prepared as part of the Ph.D. internship at the Department of Geography in NUI Galway and was supported by the research project APVV-0018-12 "Human geography and demography interactions, nodes and contradictions in a time-space network" as well as the project UK/133/2015 “The study of perceptual marginality in rural areas in Slovakia".

We would like to express our very great appreciation to all interviewees who were willing to share their time, knowledge, experience and opinions, and thus enabled us to carry out this study.

\section{References}

Andersson L., 2007. Forty years later. A retrospect on marginality and local development. In: Jones G., Leimgruber W., Nel E. (eds), Issues in geographical marginality. General and theoretical aspect. International Geographical Union: $13-28$.

Andreoli M., 1994. Development and marginalisation in Liguria region. In: Chang-Yi D., Ching Jou S., Yuh Lu Y. (eds), Marginality and development issues in marginal regions. National Taiwan University, Taipei: 41-60.

Bell S., 2009. Mental map. In: Kitchin R., Thrift N. (eds), International encyclopedia of human geography. Elsevier Ltd: 70-75. ISBN 978-0-08-044910-4.

Buchta S., 2003. Slovenský vidiek na konci dvadsiateho storočia. Sociológia-Slovak Sociological Review 2: 125-140.

CEDRA report. Report of the Commission for the Economic Development of Rural Areas Energising Ireland's rural economy. Online: http://ruralireland.ie/index.php/cedra-reports (accessed 20 Sept. 2015).

CEDRA report. Research report of the Commission on the Economic Development of Rural Ireland. Online: http:/ / ruralireland.ie/index.php/cedra-reports (accessed 20 Sept. 2015).

Che D., 2006. Developing ecotourism in First World, resource-dependent areas. Geoforum 37: 212-226.

Chromý P., 2003. Historical-geographical and cultural-geographical research on the development in border, marginal and peripheral regions in Czechia. In: Kowalczyk A. (ed.), Theoretical and methodological aspects of geographical space at the turn of the century. Theoretical and methodological challenges. Warsaw: 187-192.

Chromý P., Janů H., 2008. Regional identity, activation of territorial communities and the potential of the development of peripheral regions. In: Svatoňová H. (ed.), Geography in Czechia and Slovakia. Theory and practice at the onset of 21st century. Masaryk University, Brno: 105-107.
Conway T., Cawley M., 2012. Organisational networking in an emerging ecotourism destination. Tourism Planning $\mathcal{E}$ Development 9(4): 397-409.

Creamer C., Blair N., Keaveney K., O’Keeffe B., Driscoll J., 2009. Rural restructuring: Local sustainable solutions to the rural challenge. International Centre for Local and Regional Development.

Crewe J., 1991. Defining marginality? Tulsa Studies in Women's Literature 10 (1): 121-130.

Cullen B.T., Pretes M., 2000. The meaning of marginality: Interpretations and perceptions in social science. The Social Science Journal 37(2): 215-229.

Dingsdale A., 1999. Redefining Eastern Europe: A new regional geography of post-socialist Europe? Geography 84(3): 204-221.

Džupinová E., Halás M., Horňák M., Hurbánek P., Káčerová M., Michniak D., Ondoš S., Rochovská A., 2008. Periférnost' a priestorová polarizácia na území Slovenska. Geografika, Bratislava: 186

Falt'an L., Gajdoš P., Pašiak J., 1995. Sociálna marginalita území Slovenska. Social Marginality of Territories of Slovakia. SPACE Centrum pre analýzu sociálnej politiky: 223.

Ferrão J., Lopes R., 2004. Understanding peripheral rural areas as contexts for economic development. In: Labrianidis L. (ed.), The future of Europe's rural peripheries. Ashgate, Aldershot: 31-61.

Gregory D., Johnston R., Pratt G., Watts M., Whatmore S., 2009. The dictionary of human geography. 5th edition, Wiley-Blackwell.

Havlíček T., 2003. Are border regions peripheral territories? In: Kowalczyk A. (ed.), Theoretical and methodological aspects of geographical space at the turn of the century. Theoretical and methodological challenges. Warsaw: 193-198.

Havlíček T., Chromý P., Jančák V., Marada M., 2005. Vybrané teoreticko-metodologické aspekty a trendy geografického výzkumu periferních oblastí. In: Novotná M. (ed.), Problémy periferních oblastí. Univerzita Karlova v Praze, Přírodovědecká fakulta, Katedra sociální geografie a regionálního rozvoje: 6-24.

Hoggart K., Paniagua A., 2001. What rural restructuring? Journal of Rural Studies 17: 41-62.

Hurbánek P., 2004a. Zmeny úlohy priestorového aspektu v interpretáciách pojmov periférnost' (marginalita) a vidiek. Geografie a proměny poznání prostorové reality. Sborník z př́spěvků z Mezinárodní geografické konference (Ostrava 30-31.08.2004). Př́rodovědecká fakulta, Ostravská Univerzita: 102-110.

Hurbánek P., 2004b. Priestorový aspekt periférnosti v rurálno-geografickej a sídelno-geografickej interpretácii vidieka. Acta Universitatis Purkynianae 100: 49-60.

Jackson P., 2001. Making sense of qualitative data. In: Limb M., Dwyer C. (eds), Qualitative methodologies for geographers: Issues and debates. Arnold, London: 199-214.

Jakešová L., Vaishar A., 2012. Sustainable inner peripheries? A case study of the Olešnice micro-region (Czech Republic). Moravian Geographical Reports 20(4): 13-25.

Jeřábek M., Dokoupil J., Havlíček T., 2004. České pohraničíbariéra nebo prostor zprostredkování? Academia, Praha.

Johnston R.J., Gregory D., Pratt G., Watts M., Smith D.M. (eds), 2000. The dictionary of human geography (4th ed.). Blackwell Publishers, Oxford.

Labrianidis L., 2004. The future of Europe's rural peripheries. Ashgate, Aldershot.

Leimgruber W., 1994. Marginality and marginal regions: Problems of definition. In: Chang-Yi D. (ed.), Develop- 
ment issues in marginal regions. Marginality and development issues in marginal regions. Proceedings of the IGU Study Group. Taipei: 1-18.

Leimgruber W., 2004. Between global and local: Marginality and marginal regions in the context of globalisation and deregulation. Ashgate, Aldershot.

Limb M., Dwyer C. (eds), 2001. Qualitative methodologies for geographers: Issues and debates. Arnold, London.

Máliková L., 2013. Theoretical and methodological aspects of identifying marginal rural areas in the Slovak and Czech studies. In: Zborník príspevkov medzinárodnej konferencie doktorandov MendelNet 2013 (Brno, 20-21.11.2013). Agronomická fakulta, Mendelova Univerzita: 459-464.

Máliková L., Spišiak P., 2013. Vybrané problémy marginality a periférnosti rurálnych regiónov na Slovensku. Acta Geographica Universitatis Comenianae 57(1): 51-70.

Máliková L., Klobučník M., Bačík V., Spišiak P., 2015. Socio-economic changes in the borderland of the Visegrad group (V4) countries. Moravian Geographical Reports 23(2): 26-37.

Marada M., 2001. Vymezení periferních oblastí Česka a studium jejich znaků pomocí statistické analýzy. Geografie - Sbornik ČGS 106(1): 12-24.

McDonagh J., 2002a. Peripherality and the West of Ireland: The need for reevaluation? In: McDonagh J. (ed.), Economy, society, and peripherality: experiences from the West of Ireland. Arlen House, Galway: 97-112.

McDonagh J. 2002b. Peripheral location, human resource deficit and sustainable rural communities. In: McDonagh J. (ed.), Economy, society, and peripherality: experiences from the West of Ireland. Arlen House, Galway: 165-180.

Mehretu A., Pigozzi B.W., Sommers L.M., 2000. Concepts in social and spatial marginality. Geografiska Annaler 82 B (2): 89-101.

Musil J., Müller J., 2008. Vnitřní periferie v České republice jako mechanismus sociální exkluze. Sociologický časopis/ Czech Sociological Review 2: 321-348.

Newman D., 2006. The lines that continue to separate us: Borders in a 'borderless' world. Progress in Human Geography 30(1): 143-161.
Perlín R., Kučerová S., Kučera Z., 2010. Typologie venkovského prostoru Česka. Geografie 115(2): 61-187.

Relph E., 1976. Place and placelessness. Pion, London.

Schmidt M.H., 1998. An integrated systemic approach to marginal regions: From definition to development policies. In: Jussila H., Leimgruber W., Majoral R. (eds), Perception of marginality: Theoretical issues and regional perceptions of marginality. Ashgate, Aldershot: 45-66.

Seidl T., Chromý P., 2010. Problémy integrace marginálního území do regionálného systému: Př́klad vojenského újezdu Boletice. Geografie 115(1): 44-63.

Shobe H., Banis D., 2010. Music regions and mental maps: Teaching cultural geography. Journal of Geography 109(2): 87-96.

Sommers L.M., Mehretu A., 1998. International perspectives on socio-spatial marginality. In: Jussila H., Leimgruber W., Majoral R. (eds), Perception of marginality: Theoretical issues and regional perceptions of marginality. Ashgate, Aldershot: 135-145.

Šebová L., 2013. Identifikácia marginálnych regiónov na Slovensku. Dizertačná práca. Prírodovedecká fakulta Univerzity Komenského, Bratislava.

Tuan Y.F., 1977. Space and place: The perspective of experience. University of Minnesota Press.

Tykkyläinen M., 1998. From territorial marginality to marginality in cybersociety. In: Jussila H., Leimgruber W., Majoral R. (eds), Perception of marginality: Theoretical issues and regional perceptions of marginality. Ashgate, Aldershot: $123-132$.

Vaishar A., Zapletalová J., 2005. Marginalizace moravsko-slovenského pohraničí. In: Novotná M. (ed.), Problémy periferních oblastí. Univerzita Karlova v Praze. Přírodovědecká fakulta. Katedra sociální geografie a regionálního rozvoje: $167-176$.

Woods M., 2005. Rural geography: Processes, responses and experiences in rural restructuring. Sage, London.

Woods M., 2007. Engaging the global countryside: Globalisation, hybridity and the reconstitution of rural place. Progress in Human Geography 31(4): 485-507.

Woods M., 2011. Rural. Routledge, London. 